\title{
Paideusis
}

\section{"Liberalizing Vocational Study: Democratic Approaches to Career Education" (Emery Hyslop-Margison)}

\section{Sarah Jean DesRoches}

Volume 16, Number 1, 2007

URI: https://id.erudit.org/iderudit/1072609ar

DOI: https://doi.org/10.7202/1072609ar

See table of contents

Publisher(s)

Canadian Philosophy of Education Society

ISSN

0838-4517 (print)

1916-0348 (digital)

Explore this journal

Cite this review

DesRoches, S. (2007). Review of ["Liberalizing Vocational Study: Democratic Approaches to Career Education" (Emery Hyslop-Margison)]. Paideusis, 16(1), 67-68. https://doi.org/10.7202/1072609ar viewed online.

https://apropos.erudit.org/en/users/policy-on-use/ 
Review of

\title{
Liberalizing Vocational Study: Democratic Approaches to Career Education
}

by Emery Hyslop-Margison, Maryland: University Press of America, 2005.

\author{
SARAH DesROCHES \\ Concordia University, Canada
}

In his text, Liberalizing Vocational Study: Democratic Approaches to Career Education, Emery J. HyslopMargison attempts to break down the binary opposition between liberal education and vocational studies; this dichotomy has remained pervasive in that it has defined the Western educational context for the last twenty-five hundred years. Using a philosophical backdrop, Hyslop-Margison takes this historical clash and thrusts it into a contemporary context, providing substantial evidence to support that this division is not only constructed but that it provides ideological grounds for the systematic devaluing of educational democratic ideals, specifically in the realm of career education.

Hyslop-Margison's text sets up the dominant, polarizing, perspectives on the roles and values of education. However, the text is not limited by this superficial tension. A surface articulation of this dichotomy would be to position opposing arguments one against the other, explaining their philosophical basis, while demonstrating a preference of one over the other. However, HyslopMargison's argument does not simply present both sides of the spectrum; it marginalizes the spectrum itself by providing alternative arguments that cannot be maintained by the limited confines of a singledimensional and linear structure. An example of this is his telling of historical debates within vocational education which depict three major positions: social inclusion, social efficiency and radical perspectives. The social inclusion and social efficiency perspectives of vocational education are examples of the fundamental philosophical debate that has occurred and remains visible in a contemporary context. Social inclusion theory argues that vocational education is a means of integrating otherwise disadvantaged populations into the workforce, in an attempt to even out the social economic playing field. The third option proposed is the radical perspective. Adherents to this perspective propose that humans are legitimately ends-in-themselves and are not completely vulnerable to dominant power structures. Lying well within the tradition of critical theory, this perspective takes human agency and personal empowerment to be necessary and legitimate concerns in the field of vocational training. If we considered the social inclusion and social efficiency perspectives to be on opposite sides of a spectrum, the radical perspective would wind around this spectrum; the radical perspective takes the spectrum into consideration only in that it acts as a response to it, but refuses to be limited by it. Problematizing the dichotomy offers new perspectives on debates that have been occurring for centuries.

"As Aristotle realized more than twenty-five hundred years ago, and I have attempted to confirm, the inescapable connection between the productive, practical and theoretical dimensions of human experience are ignored at our individual and collective peril" (p.98). The concluding remarks of Hyslop-Margison's text demonstrate a heightened sensitivity to the weaknesses in both liberal and

(C) Copyright 2007. The author, Sarah DesRoches, assigns to Paideusis the right of first publication and educational and non-profit institutions a non-exclusive license to use this document for personal use and in courses of instruction provided that the article is used in full and this copyright statement is reproduced. Any other usage is probibited without the express permission of the author. 
vocational education traditions. A blatant critique of vocational training without a skeptical glimpse at its counterpart would present a (at best) biased and (at worst) boring portrait of career education. Using the Aristotelian perspective of education to poke holes in both sides of the educational spectrum provides a means of reconciling the two in error rather than exonerating one at the expense of the other. This tactic demeans the integrity of hierarchies between educational systems; simply, the Aristotelian notion of education as a cultivation of the productive, practical, and theoretical facets of a human leads one to question the often prestigious position given to the liberal arts while deeming vocational education 'lesser.' As Hyslop-Margison points out, according to Aristotle, neither of these forms of education fulfils this holistic vision of education. It is therefore illogical for one type of education to take precedence over another that falls short in an equal but opposite way.

Hyslop-Margison defines foundational rationality in career education as a means to "portray students and workers as legitimate participants in a democratic dialogue about economic, labor market and working conditions" (p.88). This, Hyslop-Margison argues, allows students to obtain a firmer grasp on the connections between themselves and their society (p.89). By treating students as rational beings, instructors unveil work related issues such as dominant power dynamics, exploitation of underprivileged workers, the history of labour unions, etc. The aim of foundational rationality that Hyslop-Margison makes explicit is to provide students with "the knowledge and perspectives that promote informed judgments and decision making" (p.89). I would argue that an underlying message can be drawn from the structure and language of his argument: by accessing their foundational rationality and identifying themselves as agents in the current labour market, there is an implicit understanding that students should then seek to overturn, or at least loosen up, these oppressive structures.

Foundational rationality combined with a language of action leaves the reader with a very strong sense that there is an expected behaviourial change that should arise due to their liberalized vocational education. Terminology such as foundational rationality is an example of how this expectation emerges; a student is provided the opportunity to practice their foundational rationality, dissecting their sociopolitical and economic context in a language that promotes participation, involvement, action. In this context it is difficult for a student to legitimize political inaction after having had this type of education. However, it is important to remember that although this program does stretch the current parameters of formal education, it still lies within this realm, thereby excluding many personal reasons for political inaction. The terms 'foundational rationality' combined with a language of action leaves the distinct impression that anything but action is irrational. This type of message could prove to be a burden rather than a blessing to some students. I recommend that the language of empowerment be expanded to underline how active participation within political and economic systems are a concern but to also value and legitimize how altering the perspectives of students is a different, but equally valuable outcome. Ultimately formal education plays an important role in the shaping of student character but cannot account for the complex web of factors that shapes a person's life and the decisions they make. Education should provide students with opportunity, not merely heightened expectations which can only be evaluated based on behavioural change, or political action. 